Article

\title{
Study Abroad in Support of Higher Education Sustainability: An Application of Service Trade Strategies
}

\author{
Eunji Oh ${ }^{1}$ and M. Minsuk Shin ${ }^{2, *}$ \\ 1 Department of International Trade, The Graduate School of Konkuk University, Sanghuh Hall \#638, \\ 120 Neungdong-ro Gawngjin-gu, Seoul 05029, Korea; oej2221@konkuk.ac.kr \\ 2 Department of International Trade, College of Social Science, Konkuk University, Sanghuh Hall \#638, \\ 120 Neungdong-ro Gawngjin-gu, Seoul 05029, Korea \\ * Correspondence: shinm@konkuk.ac.kr; Tel.: +82-2-450-3774
}

Received: 26 December 2019; Accepted: 23 March 2020; Published: 24 March 2020

\begin{abstract}
The objective of this study is to foster the sustainability of the higher education enrollment system in developed countries, where declining student enrollment is eminent, by promoting study abroad programs through utilizing service trade strategy. The methodology used in the current study is based on a co-orientation model adopted from the field of psychology. Using the co-orientation theory, this study investigates perceptual gaps (created from services' intangibility, convergence, and internationalization) between the service provider (university staff) and the customers (international students) for multiple selection criteria. The survey questionnaires were constructed based on co-orientation survey questionnaires and modified using the selection criteria that were indicated from previous studies. In conclusion, it was found that international students and the university staffs in the sample have very different perceptions on most of the international students' university selection criterion. As an implication, this study shows the factors which have the most significant difference between the perception of international students and the university staffs and offers appropriate actions to amend such gaps.
\end{abstract}

Keywords: service trade strategy; service trade; sustainability; co-orientation model; study abroad program

\section{Introduction}

Due to declining birth rates in most developed countries, higher education institutions are facing challenges in maintaining student enrolment [1,2]. In these countries, the university entrance rate is declining, and several universities have already closed or are planning to close within a few years [3].

Existing studies take several approaches on this higher education sustainability issue. Some scholars discuss governmental policies for fostering higher education [4-6]. Others take a more extreme approach and criticize and deny the need for higher education $[7,8]$. The majority of studies suggest alternative education programs to promote student enrollments for higher education institutions [9-15].

Study abroad programs are often viewed as an alternative to increase student enrollment by recruiting more international students. Higher education institutions tend to recruit international students especially from developing countries, where the student population is growing [14]. For instance, many universities and colleges in South Korea are on the verge of either reducing their total enrollment or closing the institution entirely [16]. As a solution, many Korean higher education institutions are implementing study abroad programs to attract international students to not only maintain institutional competitiveness, but subsequently, the institution's sustainability, without 
changing the current institutional frameworks [17]. However, previous studies take higher education administration perspectives and approach study abroad programs as just another education program.

The current study aims to foster the sustainability of the higher education enrollment system in developed countries, where declining student enrollment is eminent, by promoting study abroad programs through utilizing service trade strategy. Service trade refers to cross-country commercial transactions of consulting, tourism, medical care, and other services $[14,18,19]$. Service is different from a product because of its unique features. Services are characterized by intangibility [20-22], and cause larger perceptual differences between providers and customers compared with conventional products $[23,24]$. Services, also, are increasingly being provided in "converged" forms $[14,25,26]$ both intentionally and unintentionally [27]. Due to convergence, customers may misjudge or misunderstand converged service offerings. Furthermore, in service trade transactions, these perceptual incongruencies can be amplified by the differences between providers and customers in the various countries [28]. In other words, cultural and geopolitical differences further accentuate the existing perceptual difference between service providers and international customers in service trade transactions. Hence, a customized service trade strategy is required to reflect the intangible and convergent nature of services targeting international customers. The "study abroad program," which involves the convergence of education, tourism, and other services and targets international students, is an ideal prospect for the service trade strategy.

To propose a customized service trade strategy for study abroad programs, this study will investigate the level of perceptual gaps (that were created from services' intangibility, convergence, and internationalization) between the service provider and the customers for multiple factors, employing the co-orientation model from the field of social psychology. As the sample of this study, 16 Korean universities which have the majority of international students were selected. Then, this study compared the perceptions of international students' selection criteria on study abroad programs between the service provider (university staff) and service customer (international students) by conducting a survey. The survey questionnaires were made on the basis of co-orientation survey questionnaires, employing the university selection criteria for international students, which were indicated in the literatures. The collected data is analyzed and used as the basis for offering a course of action for promoting study abroad programs for the sustainability of higher education institutions.

\section{Materials}

\subsection{Declining Sustainability of Higher Education}

Higher education institutions in developed countries are becoming unsustainable due to low birthrate, changing value perceptions toward higher education, and stagnating economic development $[3,7,8]$. Higher education institutions and governments are trying to devise plans to promote sustainability, and academicians themselves are publishing studies on the same issue. Previous studies on sustainability of higher education can be grouped into four main categories as shown in Table 1.

Among these, a majority view alternative education programs as the most efficient method supporting higher education, as they maintain existing frameworks of higher education with only minor alterations. Additionally, numerous studies in this category offer study abroad programs as alternative education programs that increase student enrollments through international recruits from developing countries. In the same vein, the current study aims to expand the findings from previous research by considering study abroad programs as a form of service trade targeting international students and employing service trade strategies to foster the program. 
Table 1. Review of relevant studies on the sustainability of higher education.

\begin{tabular}{|c|c|c|c|}
\hline Category & Author & Year & Description \\
\hline \multirow{3}{*}{$\begin{array}{l}\text { Conceptual } \\
\text { definition and } \\
\text { categorization of } \\
\text { the issue }\end{array}$} & Foster [29] & 2002 & $\begin{array}{l}\text { Pointing out the current problems that higher education } \\
\text { institutions are facing }\end{array}$ \\
\hline & Wright [30] & 2010 & $\begin{array}{l}\text { Interviewed Canadian presidents and vice presidents of } \\
\text { universities' perceptions on sustainable higher } \\
\text { education institutions }\end{array}$ \\
\hline & Figueiró; Figueiró [31] & 2015 & $\begin{array}{l}\text { Reviewed the past } 63 \text { articles between } 2003 \text { and } 2013 \\
\text { regarding sustainability of higher education }\end{array}$ \\
\hline \multirow{2}{*}{$\begin{array}{l}\text { Criticism and } \\
\text { negation of higher } \\
\text { education }\end{array}$} & McLennan [7] & 2009 & $\begin{array}{l}\text { Argued that we need to rethink about the idea of the } \\
\text { university in the contemporary world }\end{array}$ \\
\hline & Zepke. [8] & 2013 & $\begin{array}{l}\text { Questioned the current teaching system of } \\
\text { higher education, specifically focused on } \\
\text { student engagement }\end{array}$ \\
\hline \multirow{3}{*}{$\begin{array}{l}\text { Governmental } \\
\text { policies }\end{array}$} & Gribble [4] & 2008 & $\begin{array}{l}\text { This study discusses about governmental policy issues of } \\
\text { higher education institutions in underdeveloped countries, } \\
\text { due to the crisis from the worldwide trend with } \\
\text { international students' mobility. }\end{array}$ \\
\hline & Haugen [5] & 2013 & $\begin{array}{l}\text { Pointed out the problems of current China's policy for } \\
\text { recruitment of Sino-African students and suggested } \\
\text { political implications for better educational environment }\end{array}$ \\
\hline & Sá et al. [6] & 2018 & $\begin{array}{l}\text { Proposed proper policies for governments using } \\
\text { comparative analysis between } 2000 \text { and } 2016 \text { in Australia, } \\
\text { Canada, England, and the USA }\end{array}$ \\
\hline \multirow{7}{*}{$\begin{array}{l}\text { Alternative } \\
\text { education programs }\end{array}$} & Fien [11] & 2002 & $\begin{array}{l}\text { Argued that higher education can maintain its } \\
\text { sustainability by adopting eclectic approach to the choice } \\
\text { of goals and research methodologies }\end{array}$ \\
\hline & Rusinko [13] & 2009 & $\begin{array}{l}\text { Proposed a matrix for higher education institutions to } \\
\text { choose a right strategy to maintain their sustainability }\end{array}$ \\
\hline & Lozano et al. [12] & 2011 & $\begin{array}{c}\text { Discussed about how universities can escape from } \\
\text { traditional education system in order to maintain } \\
\text { its sustainability }\end{array}$ \\
\hline & O'Byrne et al. [15] & 2015 & $\begin{array}{l}\text { Suggested the better curriculum design for higher } \\
\text { education institutions by analyzing } 27 \text { bachelor's and } \\
27 \text { master's programs }\end{array}$ \\
\hline & Ceulemans et al. [10] & 2015 & $\begin{array}{l}\text { Analyzed the crucial factors for sustainable higher } \\
\text { education intuitions }\end{array}$ \\
\hline & Bandyopadhyay et al. [9] & 2015 & $\begin{array}{l}\text { Studied factors influencing student participation in study } \\
\text { abroad program }\end{array}$ \\
\hline & Shin et al. [14]. & 2018 & $\begin{array}{l}\text { How consumer's perceived benefits and perceived risks } \\
\text { affect the service evaluation process of converged services }\end{array}$ \\
\hline
\end{tabular}

USA-United States of America.

\subsection{Why Service Trade Strategy on Higher Education? Intangibility and Convergence}

Previous studies on service trade can mainly be grouped into three categories as shown in Table 2.

Considering international students as the consumers of study abroad programs, it is logical to adopt the consumer behavior research framework for the current study. Existing studies report service quality, participation, engagement, and other consumption variables as the key factors that impact consumers' evaluation of services. However, existing studies overlook the key features that distinguish services from products and which influence consumer behaviors.

Compared to conventional products, services are characterized by their intangibility [32,33], which leads to larger perceptual differences between providers and customers [34,35]. Perceptual congruence between the providers and customers of a given service is important for materializing the actual purchases [36]. However, the intangible nature of service makes it rather difficult for customers to intuitively understand the features of a service or appreciate pre-purchase trials [37]. 
Another distinctive characteristic of service trade is service convergence. Services are easily converged, both intentionally and unintentionally $[14,38,39]$. When services converge, the customer decision-making process is altered in accordance with the converged and newly created service evaluation factors $[37,40]$. Thus, the changes in customer decision making processes render it rather difficult for customers to understand and evaluate the features of the converged service, resulting in a perceptual gap between the provider and the customer.

Moreover, such perceptual differences are amplified by the differences between providers and customers in different countries involved in international service trade transactions [28,41]. In other words, the perceptual difference between providers and international customers is enlarged in international service trade transactions because of the intangible and convergent nature of services, and is further accentuated by the cultural and geopolitical differences between the providers and the international customers [42]. Nonetheless, very few studies have investigated these issues in the field of service trade. Thus, novel service trade strategies are needed, reflecting the intangible and convergent nature of services targeting international customers.

Table 2. Review of relevant studies on service trade strategy.

\begin{tabular}{|c|c|c|c|}
\hline Category & Author & Year & Description \\
\hline \multirow{3}{*}{$\begin{array}{l}\text { Service trade } \\
\text { policy }\end{array}$} & Melvin [43] & 1989 & $\begin{array}{l}\text { Compared the predictability of commodity and services and } \\
\text { analyzed tariffs and welfares produced by commodities and services }\end{array}$ \\
\hline & Drake; Nicolaïdis [44] & 1992 & $\begin{array}{l}\text { Discussed about whether services must be governed by traditional } \\
\text { regulatory regimes or by the market-based rules in GATT }\end{array}$ \\
\hline & Beverelli et al. [45] & 2017 & $\begin{array}{l}\text { Demonstrated how the restrictions on service trade affect } \\
\text { manufacturing productivity }\end{array}$ \\
\hline \multirow{5}{*}{$\begin{array}{l}\text { Service } \\
\text { operation }\end{array}$} & Roth; Van Der Velde [46] & 1991 & $\begin{array}{l}\text { Emphasizes to devise a service delivery system that is congruent } \\
\text { with the desired service concept }\end{array}$ \\
\hline & Gummesson [47] & 1994 & $\begin{array}{l}\text { Operational differences of product as a center and service as a layer } \\
\text { around the product, and service as a center and product as a layer } \\
\text { around the service }\end{array}$ \\
\hline & Oliva; Kallenberg [48] & 2003 & $\begin{array}{l}\text { Defined how service strategy must be applied differently depending } \\
\text { on if it is core service with manufacturing good }\end{array}$ \\
\hline & Alam [49] & 2006 & $\begin{array}{l}\text { Categorized services as how new and innovative the service is and } \\
\text { empirically analyzed the best kind of new service. As a result, Alam } \\
\text { indicated that the best option for the service firms is not the most } \\
\text { innovated service, but the one with a low cost and less risky option }\end{array}$ \\
\hline & Lightfoot; Gebauer [50] & 2011 & $\begin{array}{l}\text { How customized or standardized the type of services must be } \\
\text { depending on the number of customers }\end{array}$ \\
\hline \multirow{3}{*}{$\begin{array}{l}\text { Service } \\
\text { consumer } \\
\text { behavior }\end{array}$} & Liang et al. [51] & 2013 & $\begin{array}{c}\text { Identified the relationship between service quality and customer's } \\
\text { switching behavior }\end{array}$ \\
\hline & Ho [52] & 2014 & $\begin{array}{l}\text { Examined relationship between consumer participation and } \\
\text { consumer evaluation of the brand }\end{array}$ \\
\hline & Rather et al. [53] & 2018 & $\begin{array}{l}\text { Analyzed the interrelationships between the consumer engagement } \\
\text { and higher order marketing constructs }\end{array}$ \\
\hline
\end{tabular}

GATT: General Agreement on Tariffs and Trade.

\subsection{Undergraduate Degree-seeking Study Abroad Programs as an Example of Service Trade}

Study abroad programs, which converge education, tourism, and other services while targeting international students, are a good example of a service trade. According to Shin et al. [14], the "study abroad programs" are classified into three types: (1) study tour (less than a semester), (2) credit-seeking study abroad (one semester to a year), and (3) degree-seeking study abroad (more than a year). Shin et al. [14] suggest credit-seeking study abroad as an appropriate case for a service trade, as it converges education and tourism services in the international market. However, study tours and degree-seeking study abroad programs are rarely considered as converged services as they show low levels of convergence with tourism and education services, respectively [14]. 
This paper suggests the possibility of considering certain segments of degree-seeking study abroad programs as part of service convergence. Degree-seeking study abroad programs could be subdivided into undergraduate and graduate programs [54]. This subdivision is meaningful in that international students seeking graduate programs place a major focus on academic factors, while those considering undergraduate programs focus on multi-dimensional factors including security, tourism, culture, and other local factors, as well as academic factors [54]. As a result, customer evaluation becomes highly complicated compared with other study abroad programs. Therefore, undergraduate degree-seeking study abroad programs are also a good example for the application of service trade strategy.

\subsection{Application of Service Trade Strategy on Undergraduate Degree-Seeking Study Abroad Programs}

Earlier studies have reported various opinions on the key factors influencing the decision-making processes of international students contemplating study abroad. This study examines the relevant literature and identifies 17 factors that affect students' selection of prospective destinations for study abroad programs. These decision-making factors are classified into five categories (see Table 3).

Table 3. Studies reporting the decision-making factors underlying study abroad programs.

\begin{tabular}{|c|c|c|c|c|c|c|c|c|c|c|c|c|c|c|c|c|c|}
\hline \multirow{2}{*}{$\begin{array}{c}\text { Factor } \\
\text { Dimensions }\end{array}$} & \multicolumn{5}{|c|}{ COST } & \multicolumn{4}{|c|}{ EDUC } & \multicolumn{3}{|c|}{ HOSP } & \multicolumn{3}{|c|}{ FNFR } & \multicolumn{2}{|c|}{ LCTN } \\
\hline & LCT & DCT & SCF & AST & TPO & IRP & DVM & DPM & IQT & FRD & HPI & GDF & HIM & I JOB & LAD & BCT & SRT \\
\hline He et al. [55] & & & & $\sqrt{ }$ & & & & & & & & & & & & & \\
\hline de Jong et al. [56] & & & & & & & & $\sqrt{ }$ & & & & & & & $\sqrt{ }$ & $\sqrt{ }$ & \\
\hline $\begin{array}{c}\text { Lindgren-Gatfield and } \\
\text { Hyde }[58]\end{array}$ & & $\sqrt{ }$ & & & & & $\sqrt{ }$ & $\sqrt{ }$ & $\sqrt{ }$ & & & & & & $\sqrt{ }$ & & \\
\hline María Cubillo et al. [59] & $\sqrt{ }$ & $\sqrt{ }$ & $\sqrt{ }$ & & & $\sqrt{ }$ & & $\sqrt{ }$ & & & & & & & & $\sqrt{ }$ & \\
\hline Moogan et al. [62] & $\sqrt{ }$ & $\sqrt{ }$ & & $\sqrt{ }$ & & & $\sqrt{ }$ & & & $\sqrt{ }$ & & & & & & & \\
\hline Navrátilová [63] & & & & & & & & & $\sqrt{ }$ & & & & & & & & \\
\hline Price et al. [64] & & & & & & & & & $\sqrt{ }$ & & & $\sqrt{ }$ & & & & $\sqrt{ }$ & \\
\hline Russel [65] & & & & & & & & & $\sqrt{ }$ & & & & & & & & \\
\hline Shanka et al. [66] & $\sqrt{ }$ & & $\sqrt{ }$ & $\sqrt{ }$ & & & & & & $\sqrt{ }$ & & & & & & & $\sqrt{ }$ \\
\hline
\end{tabular}

Note. COST: Cost (LCT, reasonableness of local living costs; DCT, reasonableness of accommodation cost (dormitory); SCF, scholarship opportunities for international students; AST, reasonableness of university tuition; TPO, variety of tuition payment options); EDUC: Education (IRP, institutional reputation; DVM, diversity of academic majors; DPM, variety of extracurricular programs for international students; IQT, instructional quality); HOSP: Hospitality (FRD, preexisting acquaintances at the target university; HPI, high ratio of international students; GDF, appropriateness of accommodation (dormitory)); FNFR: foreigner friendliness (HIM, high possibility of future immigration to host country; JOB, strong prospects for employment in the host country after graduation; LAD, exposure to local (i.e., in home country) advertisements of the university); LCTN: location (BCT, university's proximity to a metro-area; SRT, national security level).

First, studies report that the following key factors are considered by international students during their destination selection process: (1) reasonableness of local living costs (LCT), (2) reasonableness of accommodation cost (dormitory; DCT), (3) scholarship opportunities for international students (SCF), (4) reasonableness of university tuition (AST), and (5) variety of tuition payment options (TPO) $[55,58-$ 60,62,66,68,69]. We categorized these factors under a single collective category: cost (COST).

Second, the literature review indicated that international students "shopping" for study abroad programs also consider the following key factors: (1) institutional reputation (IRP), (2) diversity of academic majors (DVM), (3) variety of extracurricular programs for international students (DPM), and (4) instructional quality (IQT) [56-65,67-69]. Since these factors collectively refer to academic and scholarly activities, we grouped them under the single category: education (EDUC).

Third, the key evaluation factors involving local hospitality toward international students include the following: (1) preexisting acquaintances at the target university (FRD), (2) high ratio of international students (HPI), and (3) appropriateness of accommodation (dormitory; GDF) [57,60-62,64,66,67,69]. We grouped these factors under a single collective category: hospitality (HOSP). 
Fourth, the following factors were grouped under the category foreigner friendliness (FNFR) because they collectively refer to the university's efforts to facilitate international students' adjustment to the host country: (1) high possibility of future immigration to host country (HIM), (2) strong prospects for employment in the host country after graduation (JOB), and (3) exposure to local (i.e., in home country) advertisements of the university (LAD) [56-58,60,61,67-69].

Finally, other factors considered by international students in their evaluation of the feasibility of the location of a potential host institution include the following: (1) university's proximity to a metro-area (BCT) and (2) national security level (SRT) $[56,57,59,64,66]$. We grouped these factors under the category: location (LCTN).

\subsection{Application of Service Trade Strategy with Perceptual Difference Analysis: Co-Orientation Model}

Based on the perspective that perceptual congruency is the key element of bilateral communications [70,71], this study uses a co-orientation model [71-74] to measure the perceptual differences between the two individuals involved in the sale of study abroad programs: the service provider (university staff) and the service customer (international student).

While developing the co-orientation model, McLeod and Chaffee [73] classified the types of perceptual congruency between individual A's and B's perceptions on an objective X into (1) objective congruency, (2) subjective congruency, and (3) accuracy (see Figure 1). Objective congruency refers to the level of congruency between A's perception of $X(\mathrm{Aa})$ and $\mathrm{B}^{\prime}$ s perception of $\mathrm{X}(\mathrm{Bb})$. Subjective congruency is divided into two types: A's subjective congruency and B's subjective congruency. $A^{\prime}$ 's subjective congruency refers to the level of congruency between $A a$ and A's estimate of $\mathrm{Bb}(\mathrm{Ab})$. $\mathrm{B}^{\prime}$ 's subjective congruency refers to the level of congruency between $\mathrm{Bb}$ and B's estimate of $\mathrm{Aa}(\mathrm{Ba})$. The accuracy is divided into Accuracy I and II. Accuracy I refers to the level of congruency between $\mathrm{A}^{\prime}$ s estimate of $\mathrm{Bb}(\mathrm{Ab})$ and $\mathrm{Bb}$. Accuracy II refers to the level of congruency between B's estimate of $\mathrm{Aa}(\mathrm{Ba})$ and Aa. Earlier studies have reported that high levels of objective congruency, subjective congruency, and accuracy lead to clear bilateral communications between two individuals [72].

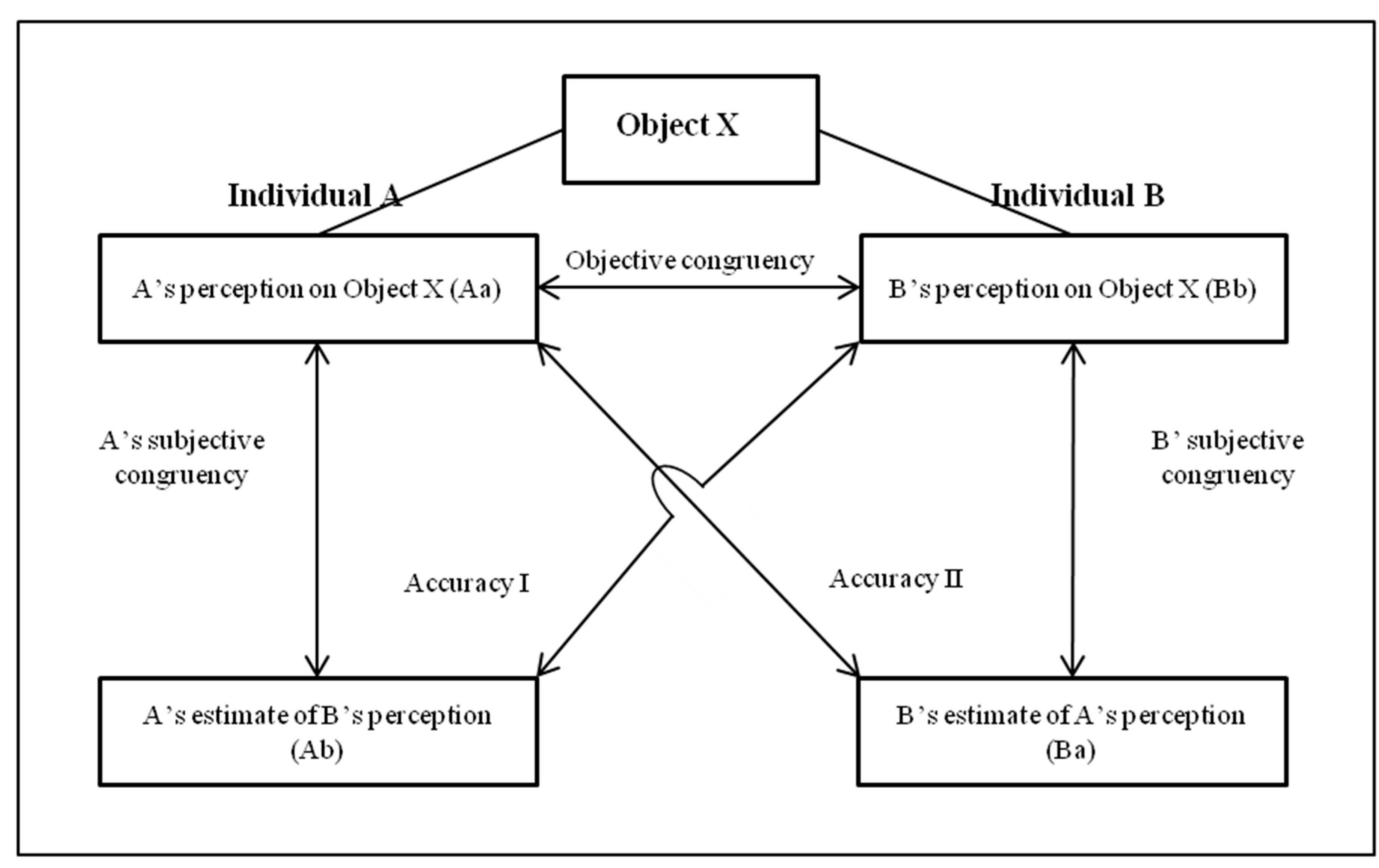

Figure 1. Co-orientation model. 


\subsection{Development of Research Questions}

The purpose of this study is to help study abroad opportunity providers develop effective marketing strategies by comparing the providers' marketing factors with the factors considered important by international students contemplating enrollment in undergraduate study abroad programs. To analyze the five factors discussed earlier and examine the perceptual differences between international students and university staff using the co-orientation model, we established the following research questions (RQs):

- RQ1: How different are international students' and university staff's perceptions regarding the importance of the cost of studying abroad (COST) in the selection of an undergraduate degree-seeking study abroad program destination?

- RQ2: How different are international students' and university staff's perceptions on the importance of education (EDUC) in the selection of an undergraduate degree-seeking study abroad program destination?

- RQ3: How different are international students' and university staff's perceptions on the importance of hospitality (HOSP) in the selection of an undergraduate degree-seeking study abroad program destination?

- RQ4: How different are international students' and university staff's perceptions on the importance of foreigner friendliness (FNFR) in the selection of an undergraduate degree-seeking study abroad program destination?

- RQ5: How different are international students' and university staff's perceptions on the importance of location (LCTN) in the selection of an undergraduate degree-seeking study abroad program destination?

\section{Method}

\subsection{Sampling}

We surveyed university staff and international students in accordance with the aim of the study: to evaluate and compare their perceptions on study abroad programs that they offer or are enrolled in. The survey was conducted at 16 universities in South Korea. These universities were selected to represent the distribution of international students in South Korea. According to "Higher Education in Korea [75]," 44.3\% of international students are enrolled in both public and private universities located in Seoul. Science and technology institutions show a high ratio of international student enrollment even though they are located outside of Seoul. Therefore, we included 14 top universities in Seoul with a combination of public, private, and women's universities. Additionally, two science and technology institutions from non-Seoul area were included in the survey (see Appendix A for the list of universities). From these 16 universities, a quota sampling method was employed to obtain a proportional number of respondents based on the 16 universities' respective sizes [76]. Detailed demographic information of the respondents (i.e., university staff and international students) is represented in Table 4. 
Table 4. Demographic information.

\begin{tabular}{|c|c|c|}
\hline \multicolumn{3}{|c|}{ University Staff/N(\%) = 120(100) } \\
\hline \multirow{3}{*}{ Place of employment } & Academic department offices & $28 \%$ \\
\hline & Department of administration, $\mathrm{PR}$, and admissions & $22 \%$ \\
\hline & Department of international affairs & $50 \%$ \\
\hline \multirow{5}{*}{ Position } & Staff (including office assistants) & $66 \%$ \\
\hline & Team leader & $18 \%$ \\
\hline & School executive & $2 \%$ \\
\hline & Professor & $12 \%$ \\
\hline & Etc. & $2 \%$ \\
\hline \multicolumn{3}{|c|}{ International Students/N(\%) = 262(100) } \\
\hline \multirow{2}{*}{ Gender } & Male & $25.5 \%$ \\
\hline & Female & $75.5 \%$ \\
\hline \multirow{2}{*}{ Marital status } & Unmarried & $100 \%$ \\
\hline & Married & $0 \%$ \\
\hline \multirow{5}{*}{ Residence period in Korea } & Within 6 months & $10 \%$ \\
\hline & 7 months 1 year & $12 \%$ \\
\hline & 1 year and 1 month to $\sim 2$ years & $22 \%$ \\
\hline & 2 years and 1 month to $\sim 4$ years & $42 \%$ \\
\hline & More than 4 year and 1 month & $14 \%$ \\
\hline \multirow{5}{*}{ Income level of financial supporter } & High & $1 \%$ \\
\hline & Mid-upper & $21 \%$ \\
\hline & Medium & $71 \%$ \\
\hline & Middle-low & $5 \%$ \\
\hline & Low & $3 \%$ \\
\hline
\end{tabular}

PR: Public Relation.

\subsection{Data Collection}

The survey was administered offline by the researcher. It was noted that 120 university staff responded to the survey. Although this sample size may not seem sufficient, an investigation of the organizational charts on university websites revealed that the total number of university staff in Seoul working in departments related to public relations and student recruitment, such as the Department of International Exchange or the Department of University Affairs, just exceeded 200. Furthermore, less than 100 of these individuals managed international students and their requirements. Additionally, 60 staff members (i.e., $50 \%$ of the total number of respondents) were working at the Department of International Exchange or University Affairs, which suggests that the sample size was sufficiently large to represent the relevant staff of all Korean universities. International students who are enrolled in degree-seeking study abroad programs were asked to answer the questionnaire and a total of 262 students answered.

\subsection{Questionnaire Structure}

The five evaluation factors (COST, EDUC, HOSP, FNFR, and LCTN) identified in this study (see Table 3) were measured using a survey questionnaire containing questions adopted or modified from existing studies (see Table 5). 
Table 5. Survey criteria.

\begin{tabular}{|c|c|c|c|}
\hline Group & Survey Criteria & & Source \\
\hline \multirow{5}{*}{ COST } & 1. Reasonableness of local living costs & LCT & e.g., Moogan et al. [62] \\
\hline & 2. Reasonableness of accommodation cost (dormitory) & DCT & e.g., María Cubillo et al. [59] \\
\hline & 3. Opportunity of scholarships for international students & SCF & e.g., Shanka et al. [66] \\
\hline & 4. Reasonableness of university tuition & AST & e.g., He et al. [55] \\
\hline & 5. Variety of tuition payment options & $\mathrm{TPO}$ & e.g., Maringe [60] \\
\hline \multirow{4}{*}{ EDUC } & 1. Institutional reputation & IRP & e.g., Shin et al. [14] \\
\hline & 2. Diversity of majors & DVM & $\begin{array}{c}\text { e.g., Lindgren-Gatfield and } \\
\text { Hyde [58] }\end{array}$ \\
\hline & 3. Variety of extracurricular programs for international students & DPM & e.g., de Jong et al. [56] \\
\hline & 4. Instructional quality & IQT & e.g., Shin et al. [14] \\
\hline \multirow{3}{*}{ HOSP } & 1. Pre-existing acquaintances at the target university & FRD & e.g., Moogan et al. [62] \\
\hline & 2. High ratio of international students & HPI & e.g., Mazzarol [61] \\
\hline & 3. Appropriateness of accommodation (dormitory) & GDF & e.g., Shin et al. [14] \\
\hline \multirow{3}{*}{ FNFR } & 1. High possibility of future immigration to host country & HIM & e.g., Yang [69] \\
\hline & 2. High of possibility for employment in host country after graduation & JOB & e.g., Soutar and Turner [67] \\
\hline & 3. Exposure to local (at home country) advertisements of the university & LAD & e.g., Telli Yamamoto [68] \\
\hline \multirow{2}{*}{ LCTN } & 1. University's proximity to metro-area & BCT & e.g., Price et al. [64] \\
\hline & 2. National security level & SRT & e.g., Duarte et al. [57] \\
\hline
\end{tabular}

Using the aforementioned co-orientation survey method, the five evaluation factors (COST, EDUC, HOSP, FNFR, and LCTN) were evaluated by measuring two to five measurement items in one step by enquiring about two individuals' perceptions and two individuals' estimates on the other individual's perceptions. For example, for the institutional reputation (IRP) dimension of the education (EDUC) factor, the first individual (university staff) was asked to rate the following two questions: (1) "Your perception of the importance of institutional reputation as a selection criterion for undergraduate degree-seeking study abroad program destinations" and (2) "Your estimate of international students' perception of the importance of institutional reputation as a selection criterion for an undergraduate degree-seeking study abroad program destination."

The second individual (international students) was also asked to rate the same question pattern, albeit with an altered subject and object: (1) "Your perception of the importance of institutional reputation as a selection criterion for an undergraduate degree-seeking study abroad program destination" and (2) "Your estimate of the university staff's perception of the importance of institutional reputation as a selection criterion for an undergraduate degree-seeking study abroad program destination." The respondents rated the level of perceived importance for each measurement item using a seven-point Likert scale, ranging from $1=$ "extremely unimportant" to $7=$ "extremely important."

\subsection{Data Analysis}

This study randomly classified the factors that were considered "important" by international students (as identified by earlier studies) into five groups. Subsequently, we conducted explanatory factor analysis to determine which factors belonged to which group. Finally, we computed Cronbach's $\alpha$ to test the reliability of each variable.

Further, we performed statistical analysis using SPSS for Windows 21.0 and AMOS 18. The difference in mean was tested using a t-test. The data set used in this study must satisfy (1) normality, (2) independence, and (3) homoscedasticity in order to use the t-test. First, regarding normality, existing studies report that people's perceptions must not be limited to five levels [77], and the more levels the Likert scale has, the greater the possibility to form normality [78,79]. In particular Leung's study [79] found that a Likert scale of more than six points has a high likelihood of following normal distribution. Thus, the data normality issue is resolved as the current study uses a seven-point Likert scale for the survey. Second, as the data was collected from two different groups of individuals (international students and university staff) in different places at different times, we believe that the data satisfies independence. Third, all analyzed data met homoscedasticity, as the F-value ranges 
from lowest, 0.016 , to highest, 19.707, and the p-value from lowest, 0.063 , to highest, $0.976(\geq 0.05)$. Moreover, existing studies using survey methods based on the co-orientation model used a t-test as their main analysis method [80-82]. Since the Likert scale is considered to be both a parametric and nonparametric procedure, existing studies report that the test results do not show significant differences regardless of using a t-test (parametric method) or the Mann-Whitney-Wilcoxon test (non-parametric method) [83]. Thus, this study uses a t-test, following previous studies' research methods, which employed a co-orientation theory.

In order to measure the co-orientation of the perception of international students (A) and the perception of university staff (B) regarding the undergraduate degree-seeking study abroad program $(X)$. This approach enabled a comparison of the areas of the universities' marketing focus with the elements that were considered important by international students.

\subsection{Co-Orientation Research Model}

To examine the difference between the perceptions of international students and university staff using the co-orientation model outlined in the Introduction section, individual A was assumed to be an international student, individual B was assumed to be a member of university staff, and X was assumed to be an undergraduate degree-seeking study abroad program (see Table 6). Finally, we computed the average of all the analyzed measures and evaluated the overall co-orientation status of the students and staff, including Accuracy I and II.

Table 6. Summary of survey directions in the co-orientation method.

\begin{tabular}{|c|c|c|}
\hline Co-Orientation Method & Code & Current Study \\
\hline Individual A & A & University staff \\
\hline Individual B & B & International student \\
\hline Object X & $\mathrm{X}$ & Study abroad program \\
\hline A's perception of $X$ & Aa & University staffs' perception of the study abroad program they offer \\
\hline B's perception of $X$ & $\mathrm{Bb}$ & $\begin{array}{c}\text { International students' perception of the study abroad program they } \\
\text { are enrolled in. }\end{array}$ \\
\hline $\mathrm{A}^{\prime} \mathrm{s}$ estimate of $\mathrm{Bb}$ & $\mathrm{Ab}$ & $\begin{array}{l}\text { University staffs' estimate of international students' perception of the } \\
\text { study abroad program }\end{array}$ \\
\hline B's estimate of Aa & $\mathrm{Ba}$ & $\begin{array}{l}\text { International students' estimate of university staffs' perception of the } \\
\text { study abroad program }\end{array}$ \\
\hline
\end{tabular}

\section{Results}

\subsection{Measurement Validity and Reliability}

Since the survey criteria used in this study were collected from many different studies, validity and reliability must be assessed. Firstly, an exploratory factor analysis (EFA) test was done in order to satisfy convergent validity. Secondly, the average variance extracted (AVE) of the factors was compared with the square of the correlations between all possible pairs of the factors in order to assess discriminant validity. Finally, Cronbach's $\alpha$ of each measurement item was calculated for reliability. The test result proved that all of the measurement items could be employed as intended in this study. The detailed result and numeral values can be found in the following sections.

\subsubsection{Convergent Validity: Selection Factors Preferred by International Students}

Table 7 depicts the five factors that generated pre-rotational Eigen values greater than one. Based on the representation of Eigen values on a scree plot, five factors were selected and varimax rotation was applied to these factors. The Cronbach's $\alpha$ test was performed to test internal consistency. An analysis of the factors considered important by the international students, whose importance was subsequently 
evaluated by university staff and international students, provided a Kaiser-Meyer-Olkin (KMO) measure of 0.798 , and Bartlett's test of sphericity yielded $\chi^{2}=1084.928(* * * p<0.001)$. This suggests that the factors were appropriately classified into the five groups as intended.

Table 7. Exploratory factor analysis of $\mathrm{Aa}$ and $\mathrm{Bb}$.

\begin{tabular}{cccccc}
\hline Abbreviation & COST & EDUC & HOSP & FNFR & LCTN \\
\hline LCT & 0.765 & 0.306 & 0.174 & 0.161 & -0.080 \\
DCT & 0.763 & 0.149 & 0.370 & 0.044 & -0.005 \\
SCF & 0.716 & 0.062 & -0.067 & 0.040 & 0.337 \\
AST & 0.715 & 0.133 & -0.068 & 0.063 & 0.362 \\
TPO & 0.632 & 0.462 & 0.154 & 0.050 & -0.087 \\
\hline IQT & 0.132 & 0.823 & 0.061 & 0.135 & 0.070 \\
DVM & 0.204 & 0.699 & 0.093 & -0.068 & 0.091 \\
DPM & 0.125 & 0.678 & 0.181 & -0.054 & -0.164 \\
IRP & 0.161 & 0.667 & -0.125 & 0.172 & 0.299 \\
\hline FRD & 0.099 & 0.115 & 0.813 & -0.012 & 0.072 \\
HPI & 0.026 & -0.140 & 0.685 & 0.282 & 0.030 \\
GDF & 0.124 & 0.214 & 0.685 & -0.019 & 0.049 \\
\hline HIM & 0.044 & 0.014 & 0.072 & 0.843 & -0.043 \\
JOB & 0.023 & -0.008 & -0.092 & 0.796 & 0.233 \\
LAD & 0.162 & 0.135 & 0.245 & 0.583 & -0.018 \\
\hline BCT & 0.123 & 0.008 & 0.173 & 0.091 & 0.871 \\
SRT & 0.242 & 0.501 & 0.020 & 0.052 & 0.557 \\
\hline
\end{tabular}

Note. Kaiser-Meyer-Olkin $(\mathrm{KMO})=0.798$, Bartlett's $\chi^{2}=1084.928\left(^{* * *} p<0.001\right)$.

4.1.2. Convergent Validity: Factors Perceived by Korean Universities as Being Important for International Students

As stated earlier, the questionnaires comprised two parts. The first part, which focused on the factors perceived important for international students by the international students themselves and the university staff, was tested for validity using exploratory factor analysis. In the second part, the factors considered important by Korean universities in the recruitment of international students as perceived by the students and staff were analyzed. Congruence was analyzed by comparing the two parts of the questionnaire with the same group; subsequently, five factors were again selected and varimax rotation was applied to each factor. The results were as follows: KMO measure $=0.881$ and Bartlett's test of sphericity $\chi^{2}=1791.584(* * *<0.001)$ for the 17 measurement items. As shown in Table 8 , the factors selected in the second round were paired with the same factors of the first round, which reconfirmed that each question was matched with the correct factors. 
Table 8. Exploratory factor analysis of $\mathrm{Ab}$ and $\mathrm{Ba}$.

\begin{tabular}{cccccc}
\hline & COST & EDUC & FNFR & HOSP & LCTN \\
\hline AST & 0.812 & 0.236 & 0.138 & 0.001 & 0.230 \\
DCT & 0.793 & 0.109 & 0.080 & 0.250 & 0.190 \\
SCF & 0.760 & -0.016 & 0.180 & 0.084 & 0.313 \\
LCT & 0.720 & 0.185 & 0.318 & 0.304 & -0.067 \\
TPO & 0.711 & 0.267 & 0.281 & 0.237 & -0.099 \\
\hline IQT & 0.124 & 0.887 & 0.139 & 0.023 & 0.153 \\
IRP & 0.171 & 0.826 & 0.091 & 0.025 & 0.223 \\
DVM & 0.147 & 0.783 & 0.093 & 0.311 & 0.029 \\
DPM & 0.100 & 0.498 & 0.278 & 0.471 & -0.184 \\
\hline JOB & 0.168 & 0.110 & 0.832 & -0.014 & 0.153 \\
HIM & 0.258 & 0.163 & 0.757 & 0.195 & -0.044 \\
LAD & 0.187 & 0.104 & 0.717 & 0.310 & 0.171 \\
\hline HPI & 0.059 & -0.049 & 0.303 & 0.756 & 0.222 \\
GDF & 0.337 & 0.236 & 0.014 & 0.741 & 0.099 \\
FRD & 0.333 & 0.347 & 0.139 & 0.587 & 0.186 \\
\hline BCT & 0.279 & 0.242 & 0.215 & 0.222 & 0.751 \\
SRT & 0.336 & 0.487 & 0.076 & 0.309 & 0.565 \\
\hline \multicolumn{5}{r}{ Note. KMO = 0.881, Bartlett's $\times 2=1791.584(* *<0.001)}$.
\end{tabular}

\subsubsection{Discriminant Validity}

In order to assess discriminant validity, the average variance extracted (AVE) of the factors were compared with the square of the correlations between all possible pairs of the factors. The square of every pair of factor resulted in smaller than each AVE values. Therefore, discriminant validity is established. The following Tables 9 and 10 display the descriptive statistics, AVE, reliabilities, and correlation matrix of all factors used in the study.

Table 9. Correlation matrix of $\mathrm{Aa}$ and $\mathrm{Bb}$.

\begin{tabular}{|c|c|c|c|c|c|c|c|c|c|c|}
\hline & $\operatorname{cosT}^{a}$ & EDUC $^{\mathbf{a}}$ & HOSP $^{a}$ & FNFR $^{\mathrm{a}}$ & LCTN $^{a}$ & $\cos ^{b}$ & EDUC $^{b}$ & HOSP $^{b}$ & FNFR $^{b}$ & $\operatorname{LCTN}^{\mathrm{b}}$ \\
\hline $\operatorname{cosT}^{\mathrm{a}}$ & 0.57 & & & & & & & & & \\
\hline EDUC $^{a}$ & $\begin{array}{c}0.36 \\
(0.13)^{* *}\end{array}$ & 0.50 & & & & & & & & \\
\hline $\mathrm{HOSP}^{\mathrm{a}}$ & $\begin{array}{c}0.40 \\
(0.16)^{* *}\end{array}$ & $\begin{array}{c}0.17 \\
(0.03)\end{array}$ & 0.60 & & & & & & & \\
\hline FNFR $^{\mathrm{a}}$ & $\begin{array}{c}0.40 \\
(0.16)^{* *}\end{array}$ & $\begin{array}{c}0.18 \\
(0.03)\end{array}$ & $\begin{array}{c}0.48 \\
(0.23)^{* *}\end{array}$ & 0.46 & & & & & & \\
\hline $\mathrm{LCTN}^{\mathrm{a}}$ & $\begin{array}{c}0.15 \\
(0.02)\end{array}$ & $\begin{array}{c}0.08 \\
(0.01)\end{array}$ & $\begin{array}{c}0.34 \\
(0.12)^{* *}\end{array}$ & $\begin{array}{l}0.034 \\
(0.00)\end{array}$ & 0.21 & & & & & \\
\hline $\operatorname{cosT}^{\mathrm{b}}$ & $\begin{array}{c}0.26 \\
(0.07) *\end{array}$ & $\begin{array}{c}0.08 \\
(0.01)\end{array}$ & $\begin{array}{c}0.21 \\
(0.05)\end{array}$ & $\begin{array}{l}00.08 \\
(0.01)\end{array}$ & $\begin{array}{l}00.08 \\
(0.01)\end{array}$ & 0.61 & & & & \\
\hline EDUC $^{b}$ & $\begin{array}{l}-0.02 \\
(0.00)\end{array}$ & $\begin{array}{l}-0.01 \\
(0.00)\end{array}$ & $\begin{array}{c}0.11 \\
(0.01)\end{array}$ & $\begin{array}{l}00.16 \\
(0.03)\end{array}$ & $\begin{array}{l}-0.19 \\
(0.04)\end{array}$ & $\begin{array}{c}0.46 \\
(0.21)^{* *}\end{array}$ & 0.52 & & & \\
\hline $\mathrm{HOSP}^{\mathrm{b}}$ & $\begin{array}{l}-0.06 \\
(0.00)\end{array}$ & $\begin{array}{l}-0.22 \\
(0.05)\end{array}$ & $\begin{array}{c}0.04 \\
(0.00)\end{array}$ & $\begin{array}{c}0.35 \\
(0.12)^{* *}\end{array}$ & $\begin{array}{c}0.03 \\
(0.00)\end{array}$ & $\begin{array}{c}0.30 \\
(0.09)^{* *}\end{array}$ & $\begin{array}{c}0.28 \\
(0.08)^{* *}\end{array}$ & 0.58 & & \\
\hline $\mathrm{FNFR}^{\mathrm{b}}$ & $\begin{array}{c}0.01 \\
(0.00)\end{array}$ & $\begin{array}{c}0.17 \\
(0.03)\end{array}$ & $\begin{array}{l}-0.01 \\
(0.00)\end{array}$ & $\begin{array}{c}0.12 \\
(0.01)\end{array}$ & $\begin{array}{l}-0.12 \\
(0.15)\end{array}$ & $\begin{array}{c}0.20 \\
(0.04) *\end{array}$ & $\begin{array}{c}0.21 \\
(0.04) *\end{array}$ & $\begin{array}{c}0.12 \\
(0.01)\end{array}$ & 0.63 & \\
\hline $\mathrm{LCTN}^{\mathrm{b}}$ & $\begin{array}{c}0.04 \\
(0.00)\end{array}$ & $\begin{array}{c}0.01 \\
(0.00)\end{array}$ & $\begin{array}{c}0.20 \\
(0.04)\end{array}$ & $\begin{array}{c}0.32 \\
(0.10)\end{array}$ & $\begin{array}{l}-0.18 \\
(0.03)\end{array}$ & $\begin{array}{c}0.49 \\
(0.24)^{* *}\end{array}$ & $\begin{array}{c}0.48 \\
(0.23)^{* *}\end{array}$ & $\begin{array}{l}00.14 \\
(0.02)\end{array}$ & $\begin{array}{c}0.26 \\
(0.07)^{* *}\end{array}$ & 0.88 \\
\hline
\end{tabular}

Note. ${ }^{*},{ }^{* *}$ denote significance at the $5 \%$ and $10 \%$ level, respectively. Values in parentheses are squared correlations; bold number shows the average variance extracted (AVE) for that construct, below of the diagonal line were correlation coefficient values; ${ }^{a}$ : university staff; ${ }^{b}$ : international students. 
Table 10. Correlation matrix of $\mathrm{Ab}$ and $\mathrm{Ba}$.

\begin{tabular}{|c|c|c|c|c|c|c|c|c|c|c|}
\hline & $\operatorname{cosT}^{a}$ & EDUC $^{a}$ & HOSP $^{a}$ & FNFR $^{a}$ & LCTN $^{a}$ & $\operatorname{cost}^{b}$ & EDUC $^{b}$ & HOSP $^{b}$ & FNFR $^{b}$ & LCTN $^{b}$ \\
\hline $\operatorname{cosT}^{a}$ & 0.55 & & & & & & & & & \\
\hline EDUC $^{a}$ & $\begin{array}{c}0.18 \\
(0.03)\end{array}$ & 0.56 & & & & & & & & \\
\hline HOSPa $^{a}$ & $\begin{array}{c}0.24 \\
(0.06)\end{array}$ & $\begin{array}{c}0.37 \\
(0.14)^{* *}\end{array}$ & 0.64 & & & & & & & \\
\hline FNFR $^{\mathrm{a}}$ & $\begin{array}{c}0.51 \\
(0.26)^{* *}\end{array}$ & $\begin{array}{c}0.30 \\
(0.09) *\end{array}$ & $\begin{array}{c}0.34 \\
(0.11)^{* *}\end{array}$ & 0.67 & & & & & & \\
\hline $\mathrm{LCTN}^{\mathrm{a}}$ & $\begin{array}{c}0.35 \\
(0.12)^{* *}\end{array}$ & $\begin{array}{c}0.57 \\
(0.32)^{* *}\end{array}$ & $\begin{array}{c}0.23 \\
(0.05)\end{array}$ & $\begin{array}{c}0.28 \\
(0.08)\end{array}$ & 0.84 & & & & & \\
\hline $\operatorname{cost}^{\mathrm{b}}$ & $\begin{array}{c}0.16 \\
(0.03)\end{array}$ & $\begin{array}{l}-0.04 \\
(0.00)\end{array}$ & $\begin{array}{l}-0.06 \\
(0.00)\end{array}$ & $\begin{array}{l}-0.04 \\
(0.00)\end{array}$ & $\begin{array}{c}0.03 \\
(0.00)\end{array}$ & 0.75 & & & & \\
\hline EDUC $^{b}$ & $\begin{array}{c}0.00 \\
(0.00)\end{array}$ & $\begin{array}{l}-0.06 \\
(0.00)\end{array}$ & $\begin{array}{l}-0.02 \\
(0.00)\end{array}$ & $\begin{array}{l}-0.04 \\
(0.00)\end{array}$ & $\begin{array}{l}-0.16 \\
(0.02)\end{array}$ & $\begin{array}{c}0.45 \\
(0.20)^{* *}\end{array}$ & 0.68 & & & \\
\hline $\mathrm{HOSP}^{\mathrm{b}}$ & $\begin{array}{c}0.04 \\
(0.00)\end{array}$ & $\begin{array}{l}-0.18 \\
(0.03)\end{array}$ & $\begin{array}{l}-0.08 \\
(0.01)\end{array}$ & $\begin{array}{l}-0.02 \\
(0.00)\end{array}$ & $\begin{array}{l}-0.11 \\
(0.01)\end{array}$ & $\begin{array}{c}0.66 \\
(0.44)^{* *}\end{array}$ & $\begin{array}{c}0.56 \\
(0.31)^{* *}\end{array}$ & 0.70 & & \\
\hline FNFR $^{\mathrm{b}}$ & $\begin{array}{c}0.20 \\
(0.04)\end{array}$ & $\begin{array}{l}-0.00 \\
(0.00)\end{array}$ & $\begin{array}{c}0.03 \\
(0.00)\end{array}$ & $\begin{array}{c}0.16 \\
(0.03)\end{array}$ & $\begin{array}{l}-0.04 \\
(0.00)\end{array}$ & $\begin{array}{c}0.49 \\
(0.24)^{* *}\end{array}$ & $\begin{array}{c}0.37 \\
(0.14)^{* *}\end{array}$ & $\begin{array}{c}0.52 \\
(0.27)^{* *}\end{array}$ & 0.70 & \\
\hline $\mathrm{LCTN}^{\mathrm{b}}$ & $\begin{array}{c}0.07 \\
(0.00)\end{array}$ & $\begin{array}{c}0.04 \\
(0.00)\end{array}$ & $\begin{array}{l}-0.01 \\
(0.00)\end{array}$ & $\begin{array}{l}-0.04 \\
(0.00)\end{array}$ & $\begin{array}{c}0.11 \\
(0.01)\end{array}$ & $\begin{array}{c}0.64 \\
(0.41)^{* *}\end{array}$ & $\begin{array}{c}0.53 \\
(0.28)^{* *}\end{array}$ & $\begin{array}{c}0.68 \\
(0.47)^{* * *}\end{array}$ & $\begin{array}{c}0.44 \\
(0.20)^{* *}\end{array}$ & 0.83 \\
\hline
\end{tabular}

Note. ${ }^{*},{ }^{* *}$ denote significance at the $5 \%$ and $10 \%$ level, respectively. Values in parentheses are squared correlations; bold number shows the AVE for that construct, below of the diagonal line were correlation coefficient values; ${ }^{\text {a }}$ :

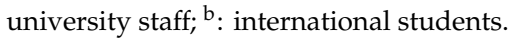

\subsubsection{Reliability}

There were five measurement items pertaining to COST in the questionnaires related to the factors considered important for international students as perceived by the students themselves, as well as by the university staff (i.e., the first part of the questionnaires). Cronbach's $\alpha$ for the five measurement items was 0.830 , which was greater than 0.60 ; therefore, the value of Cronbach's $\alpha$ was considered to be very high. The Cronbach's $\alpha$ value for the four measurement items on EDUC was high as well (0.747). The values for FNFR and for the three measurement items on HOSP were sufficient at 0.630 and 0.650, respectively. For the two measurement items on LCTN, the value was 0.573 , which was quite low; however, since it was greater than 0.50 , it was not considered to affect the overall results [84].

The average variance extracted (AVE) result for the same two measurement items was 0.642 , which was considered a satisfactory level, since it was greater than 0.50 . For measurement items on the key factors for universities recruiting international students as perceived by the international students themselves and the university staff (the second part of the questionnaires), the Cronbach's $\alpha$ of the five COST measurement items was 0.886 , which was relatively high. The Cronbach's $\alpha$ for the four EDUC measurement items was very high (0.823), and the values for the three measurement items on FNFR and HOSP were high (0.780 and 0.746 , respectively) as well. Finally, in contrast to the first part of the measurement items, Cronbach's $\alpha$ for LCTN was 0.795 , which was very high. Therefore, the reliability of all the groups in the second part of the measurement items was high.

\subsection{Objective Congruency}

Objective congruency was defined as the congruency between the perception of international students regarding Korean universities ( $\mathrm{Aa}$ ) and that of university staff regarding Korean universities $(\mathrm{Bb})$. In other words, this parameter indicated whether the factors that were considered important by international students in making decisions about studying abroad corresponded with the factors identified by university staff as being important in managing issues related to international students. Therefore, a perfect objective congruency implies that universities accurately understand the needs of international students and that their marketing strategies are efficient.

The perceptual difference between university staff and international students was statistically significant at the $95 \%$ confidence level in terms of COST, EDUC, HOSP, and LCTN. No statistically significant result was found for FNFR, which can be interpreted as a statistically significant difference 
between the universities' marketing efforts to attract international students and the decision-making factors considered important for international students in terms of COST, EDUC, HOSP, and LCTN. Therefore, such perceptual differences between students and universities imply that the universities' marketing strategies for recruiting international students are not very effective.

\subsection{Subjective Congruency}

Students' subjective congruency showed a statistically significant difference in terms of EDUC, HOSP, and FNFR at the 95\% confidence level. In the case of HOSP, the $t$-value of the factors that were considered important for students' decision-making pertaining to studying abroad (Aa, $M=4.74$ ) and the universities' perceptions of those factors as currently perceived by the students was -6.07 , which indicated a significant difference between the two perceptions. Since the average value of $\mathrm{Ab}$ was greater than that of $\mathrm{Aa}$, we could reasonably assume that the students placed more emphasis on HOSP after their arrival in Korea.

The analysis results of the university staff's subjective congruency showed a statistically significant perceptual difference at the $95 \%$ confidence level for EDUC and HOSP. On average, the difference existed for each group within HOSP, LCTN, and COST; however, the differences were not statistically significant.

\subsection{Accuracy}

\subsubsection{Accuracy $\mathrm{I}(\mathrm{Ab} / \mathrm{Bb})$}

Accuracy I analyzed the difference between university staff's efforts to achieve $(\mathrm{Bb})$ and the actual perception of results by international students $(\mathrm{Ab})$, which was derived by comparing the students' perception of the staff $(\mathrm{Ab})$ and the staff's perception of Korean universities $(\mathrm{Bb})$. As depicted in Figure 2, the Korean universities' intentions and international students' perceptions were widely different.

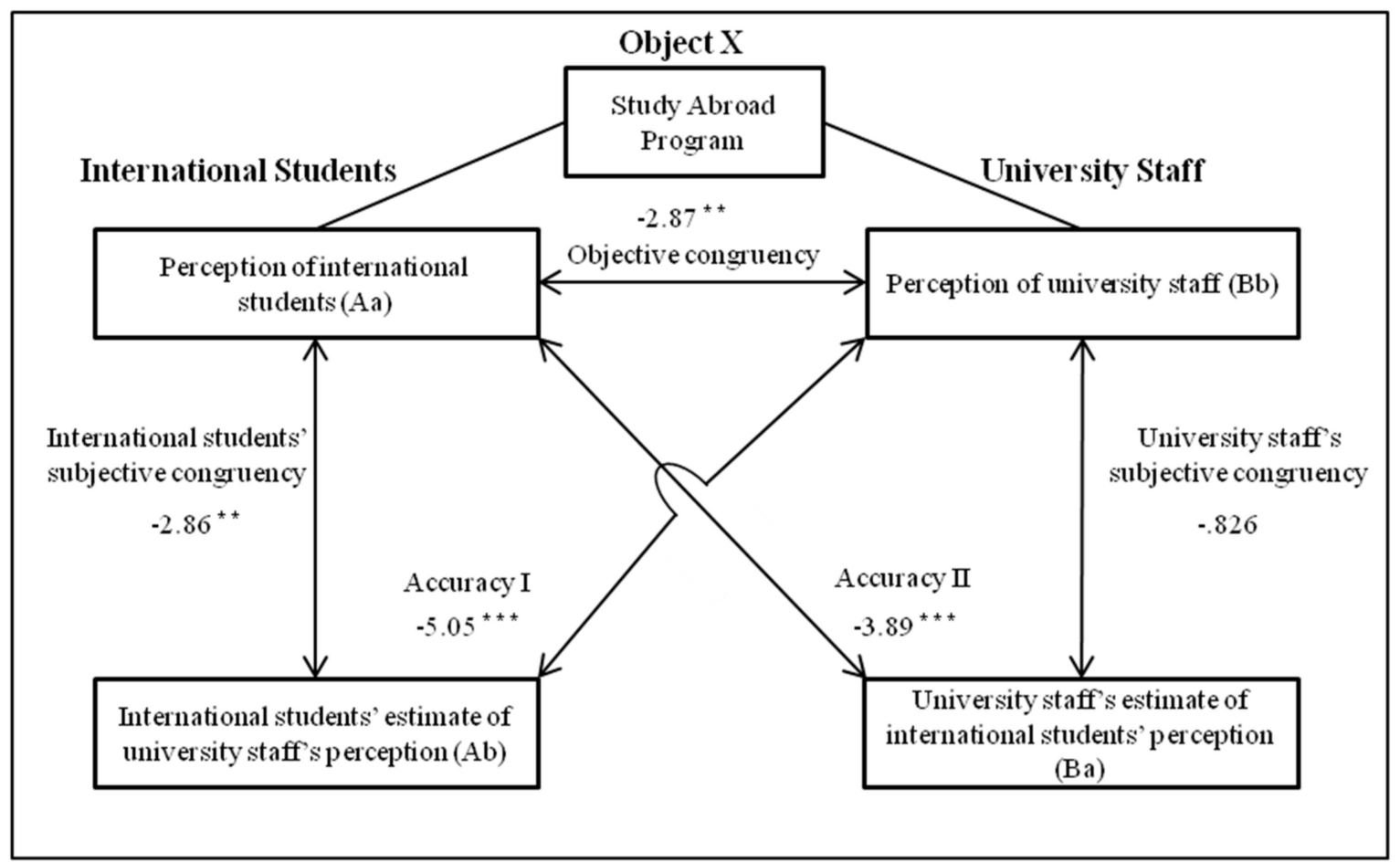

Figure 2. Co-orientation status of university staff and international students. $\left({ }^{* *} p<0.01,{ }^{* * *} p<0.001\right.$; numerical values represent the mean correlations of all the five factors) 


\subsubsection{Accuracy II (Aa/Ba)}

Accuracy II analyzed the congruency between international students' perception of Korean universities $(\mathrm{Aa})$ and university staff's perception of the international students $(\mathrm{Bb})$. A comparison of the actual expectations of students (Aa) and the staff's perception of the students' expectations $(\mathrm{Bb})$ helps determine the direction to be taken by Korean universities to attract international students. The analysis showed a statistically significant difference at the $95 \%$ confidence level for EDUC and COST. The t-value of EDUC was 8.13, which suggests a significant difference between the perceptions of staff and students. Furthermore, $\mathrm{Aa}(M=5.57)$ was greater than $\mathrm{Ba}(M=4.47)$, which indicates that the students' perception of the university staff $(\mathrm{Ba})$ was substantially lower than the actual perception of the students (Aa). For COST, $\mathrm{Aa}(M=5.73)$ was greater than $\mathrm{Ba}(M=5.09)$ as well.

\subsection{Co-orientation Status}

Figure 2 depicts the co-orientation status of the university staff and international students. The figure reveals that a significant difference was established for all tests, except the test for the subjective congruency of university staff.

\subsection{Analyses of Research Questions}

In terms of co-orientation status, all the analyzed relationships showed statistically significant differences, except for the subjective congruency of university staff. Hence, overall, Korean university staff and international students have very different perceptions regarding the key factors determining a student's selection of a study abroad destination. However, no significant difference was found in the university staff's subjective congruency test, which suggests that the staff incorrectly assumed that they were effectively addressing the needs of international students.

The results of the objective congruency test revealed that the international students' expectations exceeded what the university staff was able to provide. As indicated by the results of the Accuracy II test, the international students' expectations were completely different from the university staff's perceptions, due to which the university's marketing efforts were ineffective. In addition, the nature of marketing was very different from the expectations of the international students, as revealed by the results of the Accuracy I test, implying a significant difference between the students' demands and the perceived benefits offered by the host institution.

In particular, the results of the Accuracy I test recorded the largest perceptual difference between university staff's perceptions and international students' expectations. Among all the issues tested for Accuracy I, the largest perceptual difference was observed for the EDUC factor. According to this finding, the reputation and quality of education provided by the universities enrolling international students were much higher than those expected.

This study further investigated the subjective congruency of international students and found the biggest difference for the HOSP factor. Among the HOSP factor subgroups, a significant perceptual difference was found in terms of the importance of preexisting acquaintances in the university and a high percentage of international students. The international students' experience of the two subfactors $(\mathrm{Ab})$ significantly exceeded their expectations $(\mathrm{Aa})$, which confirms that Korean universities are committed to increasing the ratio of their international students and creating communities for them. In other words, Korean universities focus on increasing international student numbers making their admission requirements less stringent. The students, whose admission threshold was lower than that of Korean students, found that the level of EDUC exceeded their expectations. Finally, the fundamental problem is satisfying students' requirements, since the EDUC level perceived by university staff differed from that of students.

RQ1: For the COST factor, the perceptions of university staff and international students regarding objective congruency, Accuracy I, and Accuracy II showed statistically significant differences. However, there was no meaningful difference in the subjective congruency of either the staff or the students. These 
results indicate that the university staff and international students both assumed their counterparts to have the same concerns regarding cost issues. However, in reality, the two individuals were concerned about different issues associated with cost factors.

RQ2: Regarding EDUC, all the factors showed statistically significant differences, and both university staff and international students were aware of their perceptual differences. These differences may be attributed to the divergent expectations of educational levels in Korean universities; that is, the level of education was higher than that expected by the international students, and the university staff was aware of the existing high standards.

RQ3: In terms of HOSP, the objective and subjective congruencies of both the staff and students showed statistically significant differences. However, Accuracy I and Accuracy II did not yield any meaningful differences. This finding indicates that both the university staff and international students were aware of poor international marketing efforts.

RQ4: Regarding FNFR, the international students' subjective congruency and Accuracy I showed statistically significant differences, whereas the objective congruency, university staff's subjective congruency, and Accuracy II failed to produce a meaningful difference. Therefore, although university staff and international students displayed similar ideas regarding foreigner friendliness, the service trade strategy was not adequately supportive. The factors underlying this poor performance were related to the statistically significant difference in the international students' subjective congruency, indicating a perceptual gap between the international students' expectations and experiences.

On the other hand, the subjective congruency of the university staff showed no significant difference. This finding suggests that the university staff's perception was most efficient for the foreigner friendliness category. Moreover, Accuracy I indicates the difference between the staff's perception of their own performance and the international students' perception of the staff's performance in terms of foreigner friendliness. Nevertheless, Accuracy II did not show any statistically significant difference in the international students' perception of foreigner friendliness underlying their selection of university and the staff's estimate of the international students' perceptions (i.e., the staff's ultimate aim).

To elucidate the factors underlying the similarity in the perceptions of the university staff and international students and the differences between the staff's efforts and the students' experiences, we further evaluated Accuracy I in detail and discovered that they differed in terms of the "high possibility of future immigration to the host country" (HIM). The university staff assumed that many international students intended to immigrate to the host country after graduation, whereas most international students did not seriously consider the possibility of future immigration.

RQ5: Regarding LCTN, objective congruency and Accuracy I showed a meaningful difference, whereas the subjective congruency of the university staff and international students and Accuracy II did not. This finding indicates that, despite the presence of discrepancies in objective congruency and Accuracy I, the perceptions and estimates of international students regarding university staff (international students' subjective congruency) with respect to the location factor are similar and do not significantly differ from those of the university staff. Therefore, in terms of location, we consider the service trade strategy to be efficient, probably because the majority of the 16 top-tier universities implicated in this study are located in the capital city of Seoul, a location that satisfied most of the international students.

\section{Discussion and Conclusions}

\subsection{Discussion}

This study analyzes attempts by higher education institutions to resolve the sustainability problem caused by a decreasing number of new students in developed countries $[1-3,7,8]$, by recruiting international students. This study does not insist that attracting international students is the only solution to maintain the sustainability of higher education. However, since most universities are already trying to recruit more international students for the purpose of their competitiveness and 
sustainability (e.g., supernumerary admissions for international students, and cooperation with study abroad agencies), this study suggests the service trade strategy as an efficient way to operate study abroad programs for universities in order to help higher institutions maintain both the current institutional framework and their sustainability. By understanding the special features of services (i.e., intangibility, convergence, and international risks), we suggest that higher education institutions must apply service trade strategy to the provision of study abroad programs. To incorporate the special features of a service trade strategy, we emphasize the perceptual congruence between service providers and customers based on the intangible and convergent features of such services. In addition, to measure the perceptual congruency between service customers and providers in service marketing, this study proposes a new formula to derive a co-orientation model from social psychology and to be applied as a basis of survey questionnaires.

\subsection{Theoretical Implications}

Employing the basic format of a co-orientation survey questionnaire, this research applied the undergraduate university selection criterion indicated by 15 previous studies and found significant perception differences between the university staff and the international students. Considering the larger perceptual differences between customer and provider caused by special features of service trade (i.e., intangibility, convergence, and international risks) [23,24], this study applies a co-orientation model and reveals a significant perceptual difference between international students and Korean university staff, on the international students' selection criteria which were referred in the previous studies. Understanding the selection criteria of customers and reducing the perceptual gap is the basis of successful service trade strategy development [36]; therefore, from a marketing perspective, this study is meaningful in that it distinguishes between the key criteria for customer satisfaction and the criteria considered important by service providers.

Unlike earlier studies [14], which consider the credit-seeking study tour alone as an example of a converged service, this study considered the undergraduate degree-seeking study abroad program. This service, which was once considered nonconvergent, can now be defined as a converged service due to its propensity to change. In other words, with the increasing popularity of study abroad programs, the main selection criteria may not be limited to academic factors but may include nonacademic factors, such as culture, language, and so on. Finally, as described earlier, services can be converged intentionally or unintentionally [27], and the case examined in this study can be considered an example of unintentional service convergence, which generally results from naturally occurring social changes.

\subsection{Practical Implications}

The practical implications of this study include our identification of the marketing challenges in sustainability faced by higher education in Korea. The country is currently experiencing a decline in its university-aged population due to its low birthrate, and hence, Korean universities are actively recruiting international students. Based on the aforementioned analysis of perceptual differences, we make the following suggestions:

The Accuracy II test represents the difference between the students' perceptions regarding their university (what the customer wants) and the staff's estimate regarding the students' perceptions (the service provider's marketing goal). Hence, a reduction in Accuracy II may have a significant impact on the reduction of the difference in perceptions. In turn, this will increase marketing efficacy, rather than adjusting other perceptual relationships involving the promotion of undergraduate degree-seeking study abroad programs to international students.

The Accuracy II test reveals the existence of a perceptual difference between the students and university staff in terms of the key factors determining the considerations in study abroad programs. These factors are listed in order of the magnitude of difference (Table 11). Every factor considered the average score of the students to be higher than that of the university staff, which suggests that the expectations of the students were higher than those of the staff. Since these factors are listed in 
descending order in Table 11, the universities may establish more effective marketing strategies by addressing the problems associated with the factors at the top of the list.

Table 11. Accuracy II difference analysis.

\begin{tabular}{cc}
\hline The Order of Difference Magnitude & Factors \\
\hline 1st & Instructional quality (IQT) \\
2nd & Variety of tuition payment options (TPO) \\
3rd & Variety of extracurricular programs for international students (DPM) \\
5th & Diversity of majors (DVM) \\
6th & Reasonableness of local living costs (LCT) \\
7 th & National security level (SRT) \\
Note. The factors are arranged in order of the magnitude of difference.
\end{tabular}

The respondents, university staff members and international students, reported the largest perceptual difference toward instructional quality (IQT). The median values of international students' responses were higher than those of the staff. This suggests that the students considered the quality of instruction to be more important than the university staff's expectations. This finding indicates that universities can improve their marketing efforts for study abroad programs by emphasizing their faculty members' achievements, including research and professional experiences. For example, universities can highlight their faculty members' research performance or other professional experiences by adding this information to marketing brochures, websites, or emails translated into other languages, particularly targeting countries that account for the majority of the international students (e.g., China for South Korea).

Regarding the variety in TPO, allowing international students to pay their tuition in installments and in credit could enhance their satisfaction, since it is generally more difficult to finance tuition in a foreign country than in the home country. This could possibly include international online payment services, apart from international bank transfers. For example, a number of universities, including Boston University, Carnegie Mellon, and Cornell, have partnered with an online payment system, www.flywire.com, to enable international students to make tuition payments with more ease and security [85]. A bonus of offering more options for tuition payment is that this benefit applies to everyone, while a scholarship benefit only targets selected students.

A variety of extracurricular programs for international students (the third largest perceptual difference) could be better formulated via additional extracurricular activities and the addition of sports programs for international students. According to Jiani [86], other experiences (e.g., cultural experiences) are as important as coursework [86] for international students. They want to experience as much as possible while they are studying abroad. Thus, establishing many different extracurricular programs especially for international students can be an efficient way to attract more international students.

The perceptual difference in terms of the diversity of majors indicates that offering majors that are of interest to international students could provide a competitive edge to a university. Depending on the cultural and economic situation of a country, some majors are valued highly whereas others are less highly valued. Therefore, offering an array of majors according to the international students' preferences could attract them in large numbers and ultimately increase the students' competitiveness once they return to their home countries.

Universities have relatively little control over the reasonableness of local living costs and national security status. However, those universities located in relatively less expensive or safer areas can highlight these aspects in their marketing materials. On the other hand, those located in more expensive or less safe neighborhoods can devise measures to mitigate these problems and leverage these efforts in their promotional endeavors. For instance, universities can offer a cheaper school meal plan to international students. 
Finally, we address the most fundamental problem (increasing Accuracy II). Korean universities should stop focusing on increasing international student enrollment alone. By no longer obsessing over the number of international students they attract, universities should be able to market their programs more effectively. From the perspective of university management, the efficient utilization of limited resources is the best strategy to obtain the best results using the least resources.

\subsection{Limitations and Scope of Future Study}

In this study, we did not consider the barriers that could be caused by cultural differences between the host country and the international students as a factor of international students' selection criteria. The results of the current study can be expanded if future studies consider the cultural differences as part of the study abroad program selection criteria. Other than cultural differences, customer involvement, which measures the degree and length of customer participation in a given service, is an important customer evaluation factor that has been considered a crucial criterion for service evaluation by many earlier studies [87-89]. In particular, increasing attention has been paid to customer involvement by studies that reveal its direct relationship with customer loyalty $[88,89]$. Customer involvement affects both the positive and negative feelings of customers toward the criteria, whereas service convergence directly influences the criteria. Therefore, a study focused on customer involvement along with two features of this study-service intangibility and convergence-may significantly and uniquely contribute to the marketing of service industries. Finally, although this study introduces the idea of unintentional service convergence, it does not investigate the concept in detail. We suggest that future studies should further examine this concept.

Author Contributions: E.O. and M.M.S. contributed significantly to the conception of the study, data collection, analysis, and preparation of the manuscript. This study is based on the master's thesis presented by E.O. All authors have read and agreed to the published version of the manuscript.

Funding: This paper was supported by Konkuk University in 2018 (2018-A019-0226).

Conflicts of Interest: The authors declare no conflicts of interest.

\section{Appendix A}

Table A1. The list of universities that participated in the research.

\begin{tabular}{|c|c|c|}
\hline & Location & Institution \\
\hline \multirow{2}{*}{ Public } & Seoul & Seoul National University \\
\hline & Seoul & University of Seoul \\
\hline \multirow{10}{*}{ Private } & Seoul & Hankuk University of Foreign Studies \\
\hline & Seoul & Hansung University \\
\hline & Seoul & Korea University \\
\hline & Seoul & Konkuk University \\
\hline & Seoul & Kyung Hee University \\
\hline & Seoul & Myongji University \\
\hline & Seoul & Sahmyook University \\
\hline & Seoul & Sangmyung University \\
\hline & Seoul & Sejong University \\
\hline & Seoul & Sogang University \\
\hline \multirow{2}{*}{ Women's University } & Seoul & Sookmyung Women's University \\
\hline & Seoul & Ewha Woman's University \\
\hline \multirow{2}{*}{ Science and Technology } & Pohang & Pohang University of Science and Technology (POSTECH) \\
\hline & Daejeon & Korea Advanced Institute of Science and Technology (KAIST) \\
\hline
\end{tabular}




\section{References}

1. Samir, K.C.; Lutz, W. The human core of the shared socioeconomic pathways: Population scenarios by age, sex and level of education for all countries to 2100. Glob. Environ. Chang. 2017, 42, 181-192.

2. Jung, J. The fourth industrial revolution, knowledge production and higher education in South Korea. J. High. Educ. Policy Manag. 2019. [CrossRef]

3. Education Dive. Available online: https://www.educationdive.com/news/how-many-colleges-anduniversities-have-closed-since-2016/539379/ (accessed on 1 November 2019).

4. Gribble, C. Policy options for managing international student migration: The sending country's perspective. J. High. Educ. Policy Manag. 2008, 30, 25-39. [CrossRef]

5. Haugen, H.Ø. China's recruitment of African university students: Policy efficacy and unintended outcomes. Glob. Socit. Edu. 2013, 11, 315-334. [CrossRef]

6. Sá, C.M.; Sabzalieva, E. The politics of the great brain race: Public policy and international student recruitment in Australia, Canada, England and the USA. High Educ. 2018, 75, 231-253. [CrossRef]

7. McLennan, A. Role of higher education institutions (HEIs) in developing management capacity in the public sector: Customising the curriculum to build public service cadres. In Proceedings of the 13th Public Sector Trainer's Forum Conference, Birchwood Hotel, South Africa, 14-16 May 2009.

8. Zepke, N. Student engagement research in higher education: Questioning an academic orthodoxy. Teach. High. Educ. 2013, 19, 697-708. [CrossRef]

9. Bandyopadhyay, S.; Bandyopadhyay, K. Factors influencing student participation in college study abroad programs. J. Int. Educ. Res. 2015, 11, 87-94. [CrossRef]

10. Ceulemans, K.; Lozano, R.; Alonso-Almeida, M. Sustainability reporting in higher education: Interconnecting the reporting process and organisational change management for sustainability. Sustainability 2015, 7,8881-8903. [CrossRef]

11. Fien, J. Advancing sustainability in higher education: Issues and opportunities for research. High. Educ. Policy 2002, 15, 143-152. [CrossRef]

12. Lozano, R.; Lukman, R.; Lozano, F.J.; Huisingh, D.; Lambrechts, W. Declarations for sustainability in higher education: Becoming better leaders, through addressing the university system. J. Clean. Prod. 2011, 48, 10-19. [CrossRef]

13. Rusinko, C.A. Integrating sustainability in higher education: A generic matrix. Int. J. Sustain. High. Educ. 2010, 11, 250-259. [CrossRef]

14. Shin, M.M.; Noh, E.J.; Lee, J. Study abroad programs as a service convergence: An international marketing approach. Serv. Bus. 2018, 12, 253-275. [CrossRef]

15. O'Byrne, D.; Dripps, W.; Nicholas, K.A. Teaching and learning sustainability: An assessment of the curriculum content and structure of sustainability degree programs in higher education. Sustain. Sci. 2015, 10, 43-59. [CrossRef]

16. The Korea Times. Available online: https://www.koreatimes.co.kr/www/nation/2018/03/181_246221.html (accessed on 1 November 2019).

17. Knight, J. International education hubs: Collaboration for competitiveness and sustainability. New Direc. High. Educ. 2014, 2014, 83-96. [CrossRef]

18. Yeh, T.M.; Chen, S.H.; Chen, T.F. The relationships among experiential marketing, service innovation, and customer satisfaction-a case study of tourism factories in Taiwan. Sustainability 2019, 11, 1041. [CrossRef]

19. Al-Talabani, H.; Kilic, H.; Ozturen, A.; Qasim, S.O. Advancing medical tourism in the United Arab Emirates: Toward a sustainable health care system. Sustainability 2019, 11, 230. [CrossRef]

20. Pakurár, M.; Haddad, H.; Nagy, J.; Popp, J.; Oláh, J. The Service Quality Dimensions that Affect Customer Satisfaction in the Jordanian Banking Sector. Sustainability 2019, 11, 1-24.

21. Monferrer, D.; Segarra, J.R.; Estrada, M.; Moliner, M.Á. Service quality and customer loyalty in a post-crisis context. Prediction-oriented modeling to enhance the particular importance of a social and sustainable approach. Sustainability 2019, 11, 4930. [CrossRef]

22. Zhao, X.; Liu, Y.; Bi, H.; Law, R. Influence of coupons on online travel reservation service recovery. J. Hosp. Tour. Manag. 2014, 21, 18-26. [CrossRef]

23. Wong, I.A.; In Veronica Fong, H.; Tingchi, L.M. Understanding perceived casino service difference among casino players. Int. J. Comtemp. Hosp. Manag. 2012, 24, 753-773. [CrossRef] 
24. You, J.; Reiter, U.; Hannuksela, M.M.; Gabbouj, M.; Perkis, A. Perceptual-based quality assessment for audio-visual services: A survey. Signal Proceed. Image Commun. 2010, 25, 482-501. [CrossRef]

25. Milliman, J.; Gatling, A.; Kim, J.S. The effect of workplace spirituality on hospitality employee engagement, intention to stay, and service delivery. J. Hosp. Tour. Manag. 2018, 35, 56-65. [CrossRef]

26. Williams, P. Does competency-based education with blockchain signal a new mission for universities? J. High. Educ. Policy Manag. 2019, 41, 104-117. [CrossRef]

27. Wernz, C.; Thakur Wernz, P.; Phusavat, K. Service convergence and service integration in medical tourism. Ind. Manag. Data Syst. 2014, 114, 1094-1106. [CrossRef]

28. Nielsen, B.B.; Nielsen, S. The role of top management team international orientation in international strategic decision-making: The choice of foreign entry mode. J. World Bus. 2011, 46, 185-193. [CrossRef]

29. Foster, J. Sustainability, higher education and the learning society. Environ. Educ. Res. 2002, 8, 35-41. [CrossRef]

30. Wright, T. University presidents' conceptualizations of sustainability in higher education. Int. J. Sustain. High. Educ. 2010, 11, 61-73. [CrossRef]

31. Figueiró, P.S.; Raufflet, E. Sustainability in higher education: A systematic review with focus on management education. J. Clean. Prod. 2015, 106, 22-33. [CrossRef]

32. Ma, F.; Xue, H.; Yuen, K.F.; Sun, Q.; Zhao, S.; Zhang, Y.; Huang, K. Assessing the vulnerability of logistics service supply chain based on complex network. Sustainability 2020, 12, 1991. [CrossRef]

33. Pham, T.Y.; Yeo, G.T. Evaluation of transshipment container terminals' service quality in Vietnam: From the shipping companies' perspective. Sustainability 2019, 11, 1503. [CrossRef]

34. Landrum, H.; Prybutok, V.R.; Zhang, X. The moderating effect of occupation on the perception of information services quality and success. Comput. Ind. Eng. 2010, 58, 133-142. [CrossRef]

35. Alshamsi, A.; Andras, P. User perception of Bitcoin usability and security across novice users. Int. J. Hum. -Comput. Stud. 2019, 126, 94-110. [CrossRef]

36. Bilgihan, A.; Nejad, M.G.; Sreejesh, S.; Mitra, A.; Sahoo, D. The impact of customer's perceived service innovativeness on image congruence, satisfaction and behavioral outcomes. J. Hosp. Tour. Technol. 2015, $6,288-310$.

37. Kang, I.; Shin, M.M.; Lee, J. Service evaluation model for medical tour service. J. Hosp. Tour. Res. 2014, 38, 506-527. [CrossRef]

38. Jianqiu, Z.; Mengke, Y. Internet plus and networks convergence. Chin. Commun. 2015, 12, 42-49. [CrossRef]

39. Choi, H. Broadcasting and telecommunications industries in the convergence age: Toward a sustainable public-centric public interest. Sustainability 2018, 10, 544. [CrossRef]

40. Dominici, G.; Guzzo, R. Customer satisfaction in the hotel industry: A case study from Sicily. Int. J. Mark. Stud. 2010, 2, 3-12. [CrossRef]

41. López-Duarte, C.; Vidal-Suárez, M.M. External uncertainty and entry mode choice: Cultural distance, political risk and language diversity. Int. Bus. Rev. 2010, 19, 575-588. [CrossRef]

42. Quer, D.; Claver, E.; Rienda, L. Political risk, cultural distance, and outward foreign direct investment: Empirical evidence from large Chinese firms. Asia Pac. J. Manag. 2012, 29, 1089-1104. [CrossRef]

43. Melvin, J.R. Trade in producer services: A Heckscher-Ohlin approach. J. Policy Econ. 1989, 97, 1180-1196. [CrossRef]

44. Drake, W.J.; Nicolaidis, K. Ideas, interests, and institutionalization: "trade in services" and the Uruguay Round. Int. Organ. 1992, 46, 37-100. [CrossRef]

45. Beverelli, C.; Fiorini, M.; Hoekman, B. Services trade policy and manufacturing productivity: The role of institutions. J. Int. Econ. 2017, 104, 166-182. [CrossRef]

46. Roth, A.V.; Van Der Velde, M. Operations as marketing: A competitive service strategy. J. Oper. Manag. 1991, 10, 303-328. [CrossRef]

47. Gummesson, E. Making relationship marketing operational. Int. J. Serv. Ind. Manag. 1994, 5, 5-20. [CrossRef]

48. Oliva, R.; Kallenberg, R. Managing the transition from products to services. Int. J. Serv. Ind. Manag. 2003, 14, 160-172. [CrossRef]

49. Alam, I. Service innovation strategy and process: A cross-national comparative analysis. Int. Mark. Rev. 2006, 23, 234-254. [CrossRef]

50. Lightfoot, H.W.; Gebauer, H. Exploring the alignment between service strategy and service innovation. J. Serv. Manag. 2011, 22, 664-683. [CrossRef] 
51. Liang, D.; Ma, Z.; Qi, L. Service quality and customer switching behavior in China's mobile phone service sector. J. Bus. Res. 2013, 66, 1161-1167. [CrossRef]

52. Ho, C.W. Consumer behavior on Facebook: Does consumer participation bring positive consumer evaluation of the brand? EurMed. J. Bus. 2014, 9, 252-267. [CrossRef]

53. Rather, R.A.; Tehseen, S.; Parrey, S.H. Promoting customer brand engagement and brand loyalty through customer brand identification and value congruity. Span. J. Mark. ESIC 2018, 22, 319-337. [CrossRef]

54. Paige, R.M.; Fry, G.W.; Stallman, E.M.; Josić, J.; Jon, J.E. Study abroad for global engagement: The long-term impact of mobility experiences. Intercult. Educ. 2009, 20, S29-S44. [CrossRef]

55. He, Y.M.; Pei, Y.L.; Ran, B.; Kang, J.; Song, Y.T. Analysis on the higher education sustainability in China based on the comparison between universities in China and America. Sustainability 2020, 12, 573. [CrossRef]

56. De Jong, P.; Schnusenberg, O.; Goel, L. Marketing study abroad programs effectively: What do American business students think? J. Int. Educ. Bus. 2010, 3, 34-52. [CrossRef]

57. Duarte, P.O.; Alves, H.B.; Raposo, M.B. Understanding university image: A structural equation model approach. Int. Rev. Pub. Nonprofit Mark. 2010, 7, 21-36. [CrossRef]

58. Lindgren-Gatfield, R.; Hyde, M. An Examination of Two Case Studies Used in Building a Decision-Making Model. Int. Educ. J. 2005, 6, 555-566.

59. María Cubillo, J.; Sánchez, J.; Cerviño, J. International students' decision-making process. Int. J. Educ. Manag. 2006, 20, 101-115. [CrossRef]

60. Maringe, F. University and course choice: Implications for positioning, recruitment and marketing. Int. J. Educ. Manag. 2006, 20, 466-479. [CrossRef]

61. Mazzarol, T. Critical success factors for international education marketing. Int. J. Educ. Manag. 1998, 12, 163-175. [CrossRef]

62. Moogan, Y.J.; Baron, S.; Harris, K. Decision-making behaviour of potential higher education students. High. Educ. Q. 1999, 53, 211-228. [CrossRef]

63. Navrátilová, T. Analysis and comparison of factors influencing university choice. J. Compet. 2013, 5, 56-65. [CrossRef]

64. Price, I.F.; Matzdorf, F.; Smith, L.; Agahi, H. The impact of facilities on student choice of university. Facilities 2003, 21, 212-222. [CrossRef]

65. Russell, M. Marketing education: A review of service quality perceptions among international students. Int. J. Comtemp. Hosp. Manag. 2005, 17, 65-77. [CrossRef]

66. Shanka, T.; Quintal, V.; Taylor, R. Factors influencing international students' choice of an education destination-A correspondence analysis. J. Mkt. Highr. Educ. 2006, 15, 31-46. [CrossRef]

67. Soutar, G.N.; Turner, J.P. Students' preferences for university: A conjoint analysis. Int. J. Educ. Manag. 2002, 16, 40-45. [CrossRef]

68. Telli Yamamoto, G. University evaluation-selection: A Turkish case. Int. J. Educ. Manag. 2006, 20, 559-569. [CrossRef]

69. Yang, M. What attracts mainland Chinese students to Australian higher education. Studies in Learning, Evaluation, Innov. Develop. 2007, 4, 1-12.

70. Beneke, J.; Flynn, R.; Greig, T.; Mukaiwa, M. The influence of perceived product quality, relative price and risk on customer value and willingness to buy: A study of private label merchandise. J. Prod. Bran. Manag. 2013, 22, 218-228. [CrossRef]

71. Noblet, C.; Lindenfeld, L.; Anderson, M. Environmental worldviews: A point of common contact, or barrier? Sustainability 2013, 5, 4825-4842. [CrossRef]

72. Ajieh, P.C.; Uzokwe, U.N. Effective application of the co-orientation communication model in disseminating agricultural information: A review. Asian J. Agri. Ext. Econ. Sociol. 2014, 3, 217-223.

73. McLeod, J.M.; Chaffee, S.H. Interpersonal approaches to communication research. Amer. Behav. Scist. 1973, 16, 469-499. [CrossRef]

74. Singh, P.J.; Sethuraman, K.; Lam, J.Y. Impact of corporate social responsibility dimensions on firm value: Some evidence from Hong Kong and China. Sustainability 2017, 9, 1532. [CrossRef]

75. Higher Education in Korea. Available online: https://www.academyinfo.go.kr/pubinfo/pubinfo0360/ selectListLink.do (accessed on 1 November 2019).

76. Etikan, I.; Bala, K. Sampling and sampling methods. Biomet. Biostat. Int. J. 2017, 5, 215-217. [CrossRef] 
77. Cummins, R.A.; Gullone, E. Why we should not use 5-point Likert scales: The case for subjective quality of life measurement. In Proceedings of the Second International Conference on Quality of Life in Cities, Kent Ridge, Singapore, 8-10 March 2000.

78. Hodge, D.R.; Gillespie, D.F. Phrase completion scales: A better measurement approach than Likert scales? J. Soc. Serv. Res. 2007, 33, 1-12. [CrossRef]

79. Leung, S.O. A comparison of psychometric properties and normality in 4-, 5-, 6-, and 11-point Likert scales. J. Soc. Serv. Res. 2011, 37, 412-421. [CrossRef]

80. Jeong, J. Enhancing organizational survivability in a crisis: Perceived organizational crisis responsibility, stance, and strategy. Sustainability 2015, 7, 11532-11545. [CrossRef]

81. Verčič, A.T.; Colić, V. Journalists and public relations specialists: A coorientational analysis. Public Relation Rev. 2016, 42, 522-529. [CrossRef]

82. Verčič, A.T.; Verčič, D.; Laco, K. Co-Orientation between Publics in Two Countries: A Decade Later. Am. Behav. Sci. 2019, 63, 1624-1642. [CrossRef]

83. De Winter, J.F.C.; Dodou, D. Five-Point Likert Items: T test versus Mann-Whitney-Wilcoxon. Pract. Assess Res. Eval. 2010, 15, 1-17.

84. Williams, B.; Onsman, A.; Brown, T. Exploratory factor analysis: A five-step guide for novices. Aust. J. Paramed. 2010, 8, 1-13. [CrossRef]

85. BOSTINNO. Available online: https://www.americaninno.com/boston/inno-news-boston/flywire-raises120m-led-by-goldman-sachs-acquires-payments-startup/ (accessed on 6 March 2020).

86. Jiani, M.A. Why and how international students choose Mainland China as a higher education study abroad destination. High. Educ. 2017, 74, 563-579. [CrossRef]

87. Xiao, J.; Wilkins, S. The effects of lecturer commitment on student perceptions of teaching quality and student satisfaction in Chinese higher education. J. High. Educ. Policy Manag. 2015, 37, 98-110. [CrossRef]

88. Busser, J.A.; Shulga, L.V. Involvement in consumer-generated advertising: Effects of organizational transparency and brand authenticity on loyalty and trust. Int. J. Contemp. Hosp. Manag. 2019, 31, 1763-1784. [CrossRef]

89. Lee, Y.L.; Pan, L.Y.; Hsu, C.H.; Lee, D.C. Exploring the Sustainability Correlation of Value Co-Creation and Customer Loyalty-A Case Study of Fitness Clubs. Sustainability 2018, 11, 97. [CrossRef]

(C) 2020 by the authors. Licensee MDPI, Basel, Switzerland. This article is an open access article distributed under the terms and conditions of the Creative Commons Attribution (CC BY) license (http://creativecommons.org/licenses/by/4.0/). 